\title{
THE PRESS IN EIGHTEENTH-CENTURY MORRISTOWN, NEW JERSEY
}

\author{
BY E. RICHARD McKINSTRY
}

Mr. McKinstry is Associate Librarian, Printed Book and Periodical Collection, Winterthur, Delaware

1

HE press in the middle Atlantic states expanded from the region's two most important cities, Philadelphia and New York. James Parker, Isaac Collins, and Shepard Kollock, New Jersey's three pioneer printers, either served apprenticeships, worked as journeymen, or operated printing shops in these places. As time passed they, in turn, trained such noted eighteenth-century New Jersey pressmen as Shelly Arnett, Matthias Day, and John Woods. Evidence suggests that David Cree, Morristown's first printer, learned the trade from Shepard Kollock in Chatham. ${ }^{1}$

On Wednesday, June 30, 1784, Joseph Lewis, a Morristown attorney, recorded in his journal: "Cloudy \& a small shower. This day David Cree printed the first newspaper that was ever printed in Morristown." The Morristown Gazette and New Jersey Advertiser did not, unfortunately, receive the support its editor-printer had hoped for. Within a few months Cree was forced to abandon it and all other printing in Morristown. Moving to Springfield, a community only a dozen miles away, he published The Morning Herald and Weekly Advertiser, another newspaper that soon failed. ${ }^{3}$

It is not unreasonable to assume that Cree planned to fill the printing void created in northern New Jersey when Shepard Kollock left Chatham in November 1783 . That he worked with Kollock in Chatham is

1 The development of printing in New Jersey is discussed in Douglas C. McMurtrie, A History of Printing in the United States, 3 vols. (New York: R. R. Bowker, 1936), $2: 221-243,440-443$; and in William Nelson, "Some New Jersey Printers and Printing in the Eighteenth Century," Proceedings of the American Antiquarian Society, 2 I (April 1911):16-56. In the Special Collections Department of the Rutgers University Library, New Brunswick, N.J. are two indispensable sources for the study of New Jersey pressmen compiled by George C. Rockefeller and Elmer T. Hutchinson. The printers file at the American Antiquarian Society, Worcester, Mass, is a valuable tool for basic biographical information on early printers in New Jersey and the rest of the country.

${ }^{2}$ Joseph Lewis, "Journal of Joseph Lewis of Morristown, N.J. from Nov. I 2, i 783 , to Nov. 26, I795," p. 40, Edmund D. Halsey Collection, The New Jersey Historical Society, Newark, N.J.

${ }^{3}$ The Morning Herald and Weekly Advertiser is the only surviving example of Cree's work. It is part of the newspaper collection of The New Jersey Historical Society. 

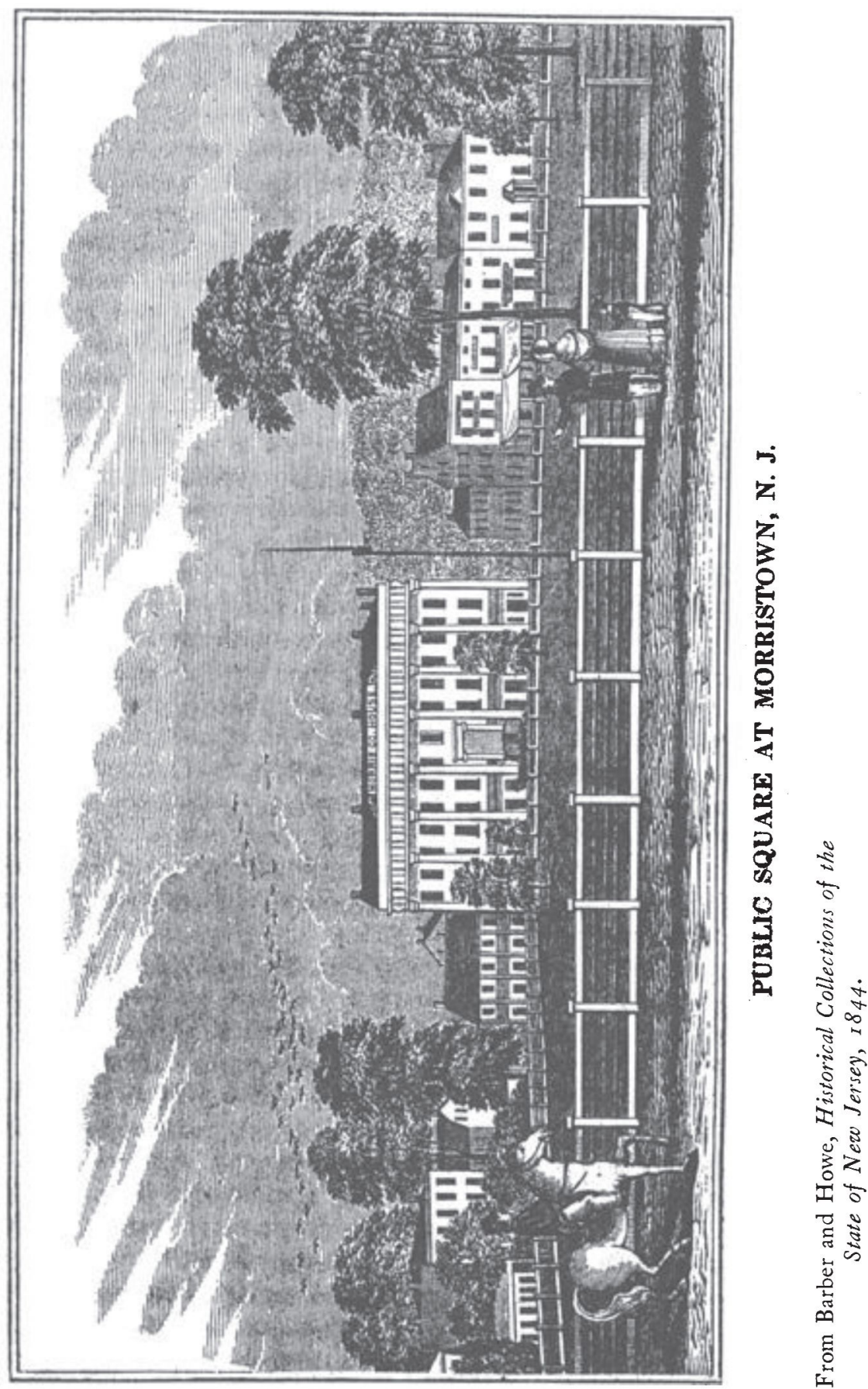
possible, since a Joseph Cree, perhaps a relative, was a journeyman under this master-printer for fifteen years. ${ }^{4}$ Rejecting coincidences of names, occupations, and residences, one might conclude that David Cree opened his own business in Morristown acquainted with the area and optimistic because of Kollock's fairly successful six-year career in a nearby village. It could not have taken Cree long to realize, however, that sufficient advertising revenues and subscribers would not be forthcoming. Ten months after the first issue of the Gazette, he still requested that patrons owing money pay their debts. ${ }^{5}$ In addition, Cree could not rely on the army as Kollock had during the Revolutionary War for patronage, financial assistance, and supplies. A town of 3,000 people could support neither a newspaper nor a printing office.

Printing did not return to Morristown until I 797 when Caleb Russell, a lawyer, local official, and civic leader, purchased an entire printing shop and asked Elijah Cooper to run it for him. ${ }^{6}$ It is conceivable that Russell bought his equipment from John Hamilton of Elizabethtown, who advertised that "printers . . . may be supplied with presses, made on an approved plan, after the best manner, and at three weeks notice . . . for seventy-five Dollars, which considering the manner in which he finishes his presses, he flatters himself will be considered as a moderate compensation." In 1797 a printer in Morristown might have looked forward with some certainty to making a comfortable living. An academy whose reputation drew students from hundreds of miles, two active church congregations, a growing government locally situated, attorneys needing various legal forms and publications, and a financial sponsor all contributed to a feeling of well-being. An emerging party system encouraged the establishment of the press for political reasons.

On June I 8, I 794, Cooper began his printing career in Walpole, New Hampshire as an apprentice to David Carlisle. Indentured until October 30, 1797, he ran away on October 4, 1796, and settled in Morristown where he remained as Caleb Russell's printer until November r797. Returning to his native state, he started to publish The Rising Sun in Keene on April 7, I798. In the meantime, David Carlisle had initiated a lawsuit against Cooper and his father for his disappearance. Cooper's short-

\footnotetext{
${ }^{4}$ John R. Anderson, Shepard Kollock: Editor for Freedom (Chatham, Chatham Historical Society, 1975), p. I4.

${ }^{5}$ Morning Herald and Weekly Advertiser, April 27, 1785.

${ }^{6}$ Israel Russell, "Extracts from Papers Received from Mrs. Israel Russell, Relative to the Establishment of the First Academy, Library, and Printing Press, in Morristown," Proceedings of the New Jersey Historical Society, ist ser. $8(1856 / 59): 32$.

${ }^{7}$ New York Daily Advertiser, June 16, 1796.
} 
lived second New Hampshire printing career ended in June I 798, when he moved to Boston. He subsequently traveled to Tortola, the West Indies, and died there early in $1801 .{ }^{8}$

During his stay in Morristown, Cooper printed the Morris County Gazette and until recently has been credited with two 1797 imprints: A Jerseyman's Common Sense, by Isaac Price and The Morristown Ghost, probably by Ransford Rogers. While Price's twelve-page pamphlet presented the usual arguments against American friendship with France, Rogers' work summarized his now-legendary hoax of some of Morristown's more gullible residents. Although Charles Evans and William Nelson both indicate that Common Sense came from Cooper's press, it is likely that Shepard Kollock actually issued it from Elizabethtown. ${ }^{9}$ It is hard to imagine Caleb Russell, a Jeffersonian, permitting the publication of such a thing at a shop he financed. Moreover, it is reasonable to conclude that Kollock printed Common Sense, since the arrangement of ornaments and lines at the top of page one matches the designs in A Collection of Poems on Religious and Moral Subjects Extracted from the most Celebrated Authors and Amusement Hall; or an Introduction to the Attainment of Useful Knowledge, two of his other I 797 imprints. ${ }^{10}$ Crediting Elijah Cooper with The Morristown Ghost is, likewise, incorrect. Its inclusion in Evans' American Bibliography under Cooper's name is perplexing, since the single copy Evans supposedly located is non-existent and since no earlier or later list of Morristown imprints records it. ${ }^{11}$ Presumably, he somehow confused a 1792 edition of the Ghost printed in Newark by John Woods with $A$ Collection of Essays, on a Variety of Subjects in Prose and Verse, a I797 Woods book, which contained the earlier publication as one of its parts. In short, there never was a 1797 edition of The Morristown Ghost. ${ }^{12}$

Early in 1798 Jacob Mann replaced Cooper. Unlike his predecessor, Mann was trained locally and was more settled in his occupation, work-

${ }^{8}$ The Elmer T. Hutchinson Collection contains the basic biographical information on Elijah Cooper.

${ }^{9}$ Charles Evans, American Bibliography, 14 vols. (Chicago and Worcester: Privately printed and American Antiquarian Society, 1912-1959), 3441r. Citation is to item number, not page number. William Nelson, Check-List of the Issues of the Press of New Jersey, ${ }_{1723},{ }^{7} 7^{28},{ }_{1754-1800}$ (Paterson, N.J.: Call Printing and Publishing Co., I 899 ), p. 20.

${ }_{10}$ George C. Rockefeller Collection.

${ }^{11}$ Evans, American Bibliography, 24754.

12 George C. Rockefeller, Communication to the editor, Proceedings of the New Jersey Historical Society 53 (Winter 1935):271; Donald A. Sinclair, "A Collection of Essays, on a Variety of Subjects': a Note," Proceedings of the American Antiquarian Society, 88 (1978):114-119. 
ing and residing in Morristown almost continually for nearly thirty years. He issued Cooper's Morris County Gazette until May I 5 and then established its successor, the Genius of Liberty, the following week. ${ }^{13}$ In addition to this newspaper, Mann printed ten identifiable items through $\mathrm{I} 800$, not including the forms and blanks usually expected from an active printing office.

One week before the Gazette first appeared, Newark's Centinel of Freedom reacted to the prospect of another competitor. Its proprietor, Daniel Dodge, offered congratulations and hoped that "beneficial effects" would result. "Many persons in that town and county who do not now take any paper," he wrote, "will thereby be induced to take, by which means useful information may be diffused, and the people become instructed in their civil and political rights." Dodge was confident, however, that the quality of his own paper would prevent readers from deserting it, "although they may patronize that paper [the Gazette]." It was a time, he concluded, when the Centinel would be especially attentive to the wars in Europe and the cloudy domestic political situation and would "faithfully detail" all news in its columns. ${ }^{14}$

Despite Daniel Dodge's optimism, it was difficult to build the circulation of Morristown's new weekly paper. Unreliable delivery riders, existing competition, and insufficient funds militated against the success of the venture. In an effort to circumvent these problems, Elijah Cooper and Jacob Mann promoted their newspapers in at least three ways. First, if someone purchased eight copies of an issue to resell, he received a ninth without charge; if he obtained twelve creditable subscribers and became accountable for them, he earned a copy of each issue "for his trouble." Second, in I 799 a list of civil officers serving in Morris County was distributed free to subscribers. To those who did not subscribe, the list was available at the printing office for six cents. Mann's generosity lasted only one year-in I 800 the civil list appeared in the Genius of Liberty's May first issue. Finally, subscribers were permitted to pay in produce rather than in dollars, permitting the printer to receive food and supplies directly from his customers. ${ }^{15}$

These inducements no doubt encouraged Morristown's residents to patronize their local newspaper. After doing so, however, some had to

${ }^{13}$ Clarence S. Brigham, History and Bibliography of American Newspapers, $1690-$ 1820, 2 vols. (Worcester: American Antiquarian Society, 1947) 1:500-50 I.

${ }^{14}$ Centinel of Freedom, May i $7,1797$.

${ }^{15}$ The civil list was advertised in the Genius of Liberty on June 27,1799 , while the other promotions appeared regularly, nearly every week. 
be prodded for payment. Only four-and-one-half months after his first issue, Elijah Cooper wrote somewhat timidly that "the continual expense in procuring necessaries to support the office must be a sufficient apology, for this application [for payment] to our customers." ${ }^{16}$ Two years later Jacob Mann sounded more serious: "To defray the expenses which have already accrued ... and for the necessary articles of life, we are now impelled, with urgency, to solicit of those who are in arrears, the favor of a settlement, and discharge of their respective accounts." ${ }^{17}$ In October I 800 Mann revealed that some subscribers' "accounts have been accumulating since the establishment of the press in this town [I797]." $\mathrm{He}$ stated that a penalty fee would be required from all who did not make the standard quarterly payment and called for the immediate settlement of accounts more than six months outstanding. ${ }^{18}$ This unenviable monetary situation in Morristown was not unique. Eighteenth-century printers everywhere constantly faced a precarious financial condition. $^{19}$

These problems of circulation must have been frustrating for Mann, who felt strongly about the value of the newspaper. Writing in the January 2, I 798, issue of the Gazette, he discussed the importance of reading newspapers and, interestingly enough, stressed their utility as an educational tool. "Do you want your child to improve in reading?" he asked. "Give him a News-Paper, it furnishes a variety, some part of which must infallibly touch his fancy." Posing and answering another question, he continued: "Do you wish to instruct him in geography? nothing will so indeliably [sic] fix in his mind the relative situation of different places, as the stories and events published in News-Papers." $\mathrm{He}$ argued that if parents encouraged their children to read newspapers they would promote learning which, in turn, would ensure "the liberty of posterity." Mann concluded: "News-Papers supply the want of schools-the want of company, and the want of preaching; they have the power to mitigate the pains of the afflicted-the distresses of the sorrowful-check the wild extravigance [sic] of the licentious,-bring home the prodigal, and ... to do good in all ranks, denominations, characters, and situations in life."

${ }^{16}$ Morris County Gazette, October I1, I 797.

17 Genius of Liberty, November 2, 1799.

${ }^{18}$ Ibid., October 30 , I 800.

${ }^{19}$ Lawrence C. Wroth, The Colonial Printer (Charlottesville, University Press of Virginia, Dominion Books, 1964), pp. 232-233; Clarence S. Brigham, Journals and Journeymen (Philadelphia, University of Pennsylvania Press, 1950), pp. 23-26. 
In design and content the Morris County Gazette and the Genius of Liberty were representative eighteenth-century newspapers. Measuring I I $x$ I 8 and invariably consisting of four pages, each number usually contained three-and-one-half to four columns of advertisements, legal notices, and public announcements. Local news was unimportant and occupied at best only a small portion of the space. Although there was a column headed "Morristown," more often than not it reported and commented on national and foreign matters. The editors did not repeat items of local interest that they expected to be passed by word of mouth. Reflecting an interest in literary material, the Genius of Liberty regularly printed poetry and vignettes. Longer works, such as John Moore's Journal were serialized. It was not uncommon to find in the columns of the two newspapers reports from government officials, letters that considered the issues of the day from correspondents identified only by pseudonyms, and critical comments dealing with local, national, and international questions.

The most ambitious single printing undertaking in eighteenth-century Morristown was Jacob Mann's I 799 publication of the Spirit of Despotism, by Vicesimus Knox. In short, this volume argued against despotic governmental rule and exhorted citizens to familiarize themselves with their nation's laws. "It is their duty," Knox proclaimed, "to watch over the possessors of power, lest they should be prevented, by the encroaching nature of power, from leaving to posterity that freedom which they inherited." ${ }^{20}$

Jacob Mann regularly used the pages of the Genius of Liberty to advertise this publication. In a one-and-one-half column proposal he announced his intention of issuing the Spirit of Despotism by subscription and recommended it to his readers "although this work was written in Great Britain, and published for the instruction of the people thereof." Extracts from Knox's preface and "Heads of the different Subjects" were included to entice the public to subscribe to the volume. ${ }^{21}$ Ten weeks later Mann printed an eleven-paragraph extract from the book as a further reminder to his readers. ${ }^{22}$ On June 13 he wrote: "Those persons who hold subscription papers for the Spirit of Despotism will please return them to the Printer, that the Subscribers may be known, as the Book will shortly be ready for Publication."23 Finally, nearly seven months after first advertising his project, Mann asked the sub-

20 Genius of Liberty, April I 8, 1799.
22 Ibid., April I 8, I 799.
${ }^{21}$ Ibid., February 7, 14, 28, 1799.

${ }^{23}$ Ibid., June I 3, July 4, 18, I 799. 
scribers to call for their copies. ${ }^{24}$ Two weeks passed before the book was offered to the public - at the cost of seventy-five cents. ${ }^{25}$ In subsequent issues of the Genius of Liberty Mann noted that stores in Bottle Hill (now Madison), Whippany, and Mendham had copies for sale. ${ }^{26}$

During the eighteenth century, printers commonly solicited subscribers for their prospective publications through similar newspaper notices. Referring to Philadelphia's colonial printers, one observer wrote that such announcements suggested that printers financed most of their venture printing this way. ${ }^{27}$ For inexplicable reasons Mann advertised in no other northern New Jersey newspapers than his own. Neither the Centinel of Freedom, the Newark Gazette, nor the New Jersey Journal contained notices about this book.

As a young country printer just beginning his career, Mann had to be concerned with producing the Spirit of Despotism in a most economical way: He saved money by using his own newspaper for publicity, and, most likely, encouraged sales elsewhere by exchanging his work for those of other printers. Rather than setting this volume in type from manuscript, Mann used an earlier Philadelphia edition as his copy. ${ }^{28}$ Although not opting for a page-for-page reprint, he could thus calculate with precision the amount of paper needed and could schedule composition time so as not to conflict with other assignments. Irregular signatures suggest that Mann did not tie up his type for too long, thereby allowing for concurrent work.

In fact, while printing and distributing this volume, Mann issued for six cents a copy a twenty-four page pamphlet entitled Amusement-Hall; or, a Collection of Diverting Stories, and Extraordinary Facts, with an Account of the Art of Ventriloquism; and other Entertaining Matter. Again, irregular signatures indicate that this publication must have been printed in piecemeal fashion as type and time at the press became available. The Amusement-Hall is a collection of six tales ranging from religious fanaticism to cannibalism to love that resemble the short stories in eighteenth-century and early nineteenth-century English periodicals. ${ }^{29}$

24 Ibid, August 29, I 799.

${ }^{25} \mathrm{Ibid}$., September $12,1799$.

${ }^{26}$ Ibid., September 1 2, October 24, 1799 . The proprietors of the stores were Jonathan Richards (Bottle Hill), Gray and Voorhies (Whippany), and Daniel Minton (Mendham).

${ }^{27}$ Peter J. Parker, "The Philadelphia Printer: A Study of an Eighteenth Century Businessman," Business History Review, 40 (Spring 1966):35.

${ }^{28}$ This edition was printed in 1795 by Thomas Lang and Stephen C. Ustick for themselves and Mathew Carey.

29 The tales are: The Sexton of Cluni, The Salutary Effects of Holy-Water, Art of Ventriloquism, A Venetian Story, Extraordinary Adventure, and Wonderful Fact. 
American printers, with weak international copyright agreements, regularly "borrowed" such literary items for their newspapers and other publications. Even though this pamphlet does not record a printer, there is no reason to assume that it came from any other office than Jacob Mann's. ${ }^{30}$

At least two eighteenth-century Morristown imprints reflected the national and local esteem held for George Washington. On December 26, I799 Jacob Mann increased the size of his newspaper by half to tell his readers how Washington's death was observed elsewhere. Consisting of the two inside pages and thus considered a separate imprint by bibliographers, $A$ Memorial of the Respect Paid to the Man First in WarFirst in Peace, and First in the Affections of the American People described the services held in Philadelphia on December 26 and in New York on December 3I. It listed in detail the order of each city's funeral procession and included poetry written for the occasion.

Two weeks after Washington's death, Rev. John I. Carle, pastor of the Rockaway Presbyterian Church, delivered a sermon eulogizing the "fallen hero." Comparing Washington's accomplishments with those of Moses, Carle insisted that there be a period of national mourning for the former President. Curiously enough, this sermon discussed Washington's exploits in the armed forces at length, but mentioned his political career only in passing. Since Washington had at one point during the Revolutionary War resided in Morristown with the Ford family, local residents obviously felt themselves better acquainted with his military reputation. On February I3, I 800, Mann offered this sermon for sale in pamphlet form for one shilling. ${ }^{31}$

In all probability Mann printed another address memorializing Washington. In the March 6, I800, issue of the Genius of Liberty he advertised: "(Price One Shilling) An Oration commemorative of the Death of Gen. Washington, Delivered at Rockaway, on the 22nd of Feb. by Bernard Smih, Jun." Although Mann did not credit himself or any other printer with publishing this pamphlet, the proximity of Rockaway to Morristown and Mann's earlier Rockaway sermon lead to the conclusion that he also printed this oration. No copy is known to have survived.

${ }^{30}$ Ronald L. Becker, "From the Collections: Amusement-Hall, An Unusual Morristown Pamphlet," New Jersey History 93 (Autumn-Winter 1975), p. 129.

${ }^{31}$ In the February 6, I 800 issue of the Genius of Liberty Mann announced his intention of issuing the sermon "in the course of the present week." On February 20 he advertised the pamphlet for one shilling. 


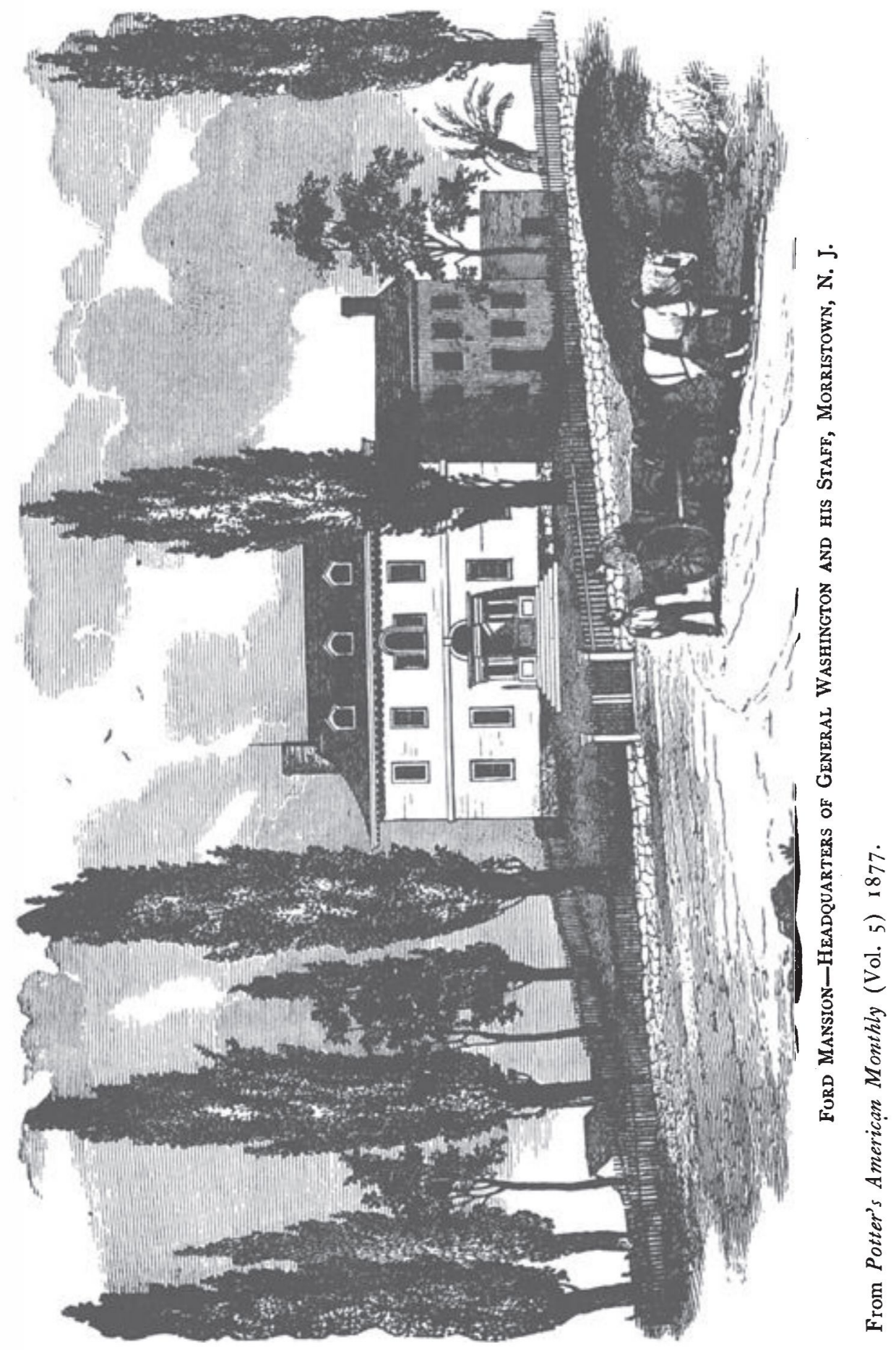


Mann's admiration for Washington was counterbalanced by his low opinion of William Blount, whose notoriety stemmed in part from questionable dealings in western lands. As a member of the United States Senate, Blount involved himself in a plot to transfer the control of Spanish Florida and Louisiana to Great Britain. The Senate expelled him by twenty-five-to-one vote when the plan was uncovered. Jacob Mann responded to these events by printing in an "extraordinary" supplement to the January 9, I 798 issue of the Morris County Gazette a portion of the report issued by the House of Representatives on Blount's behavior. Called Report of the Committee of the House of Representatives of the United States Appointed to Prepare and Report Articles of Impeachment A gainst William Blount, a Senator of the United States, Impeached of High Crimes and Misdemeanors, ${ }^{32}$ it contained twelve letters to and from Blount and his co-conspirators concerning their intended operations. Mann must have been disappointed when the Senate, one year later, dropped the proceedings after deciding that it lacked jurisdiction in the case.

Like his eighteenth-century counterparts, Jacob Mann relied on job printing and the selling of forms to make part of his living. The first of three instances of special work was recorded on February 8, I 798, when the trustees of the Morristown Presbyterian Church "Voted that the Treasurer Credit Mr. Russell [Mann's sponsor] one dollar for printing letters circulated in the Congregation." ${ }^{\prime 3}$ Since the parishioners were at that time most interested in finishing their meeting house, this letter presumably related to that concern.

As the eighteenth century drew to a close, partisan political presses were established throughout the country to debate such issues as the naturalization, Alien, and Sedition acts, increased government spending, Napoleonic conquests, and freedom of the press. Unlike many of his contemporaries, Jacob Mann did not print material exclusively for one party. On December I6, I 800 , Morris County Federalists met to proclaim their support for candidates to Congress; one day later the Republicans did the same. To publicize further their positions, both parties contracted with Mann to print the major speech delivered at each meeting. Entitled An Address to the Citizens of the County of Morris, the

32 During the year John Fenno, a Philadelphia printer widely known for his Federalist sympathies, printed the entire report in book form.

${ }^{33}$ Morristown Presbyterian Church, History of the First Presbyterian Church, Morristown, N.J. . . the Combined Registers, from ${ }^{2} 742$ to 1885 (Morristown, Banner Steam Print, I880-1891?), p. 27. 
Federalist paper emphasized overall national prosperity and successful political isolation from Europe. The opposition, in Republican Meeting ... to the Citizens of the County of Morris, contended that basic freedoms were being eroded through restrictive legislation and that Federalist candidates did not represent the common man. Apparently the Republicans presented their arguments more effectively, since in 1800 they elected five representatives to Congress from New Jersey, while the Federalists elected none.

There were as many forms from Mann's office as one would expect from a country printer's press. With few exceptions, the columns of the Genius of Liberty contained weekly advertisements for "Blank deeds, mortgages, bonds, indentures for apprentices, summons, subpoenas, tickets, veneries, recognizances for justices to take under the Sixty Dollar Act, and a variety of other blanks." ${ }^{34}$ Caleb Russell may have been one of the best customers for these forms. When he died he left, according to his inventory, "Lots of Blanks in Office."

Legal matters did not escape Mann's attention. On March I 5, r 798 , New Jersey's legislature passed the so-called Sixty Dollar Act to simplify litigation in civil court cases involving up to sixty dollars in damages. As a result, constables were entitled to serve warrants that ordered the appearance of offenders before local justices of the peace. Guilty verdicts mandated the completion of recognizances describing the particulars of each case and recording the people involved. Only five weeks after this bill was passed in Trenton, Jacob Mann offered it for sale as a twentythree page pamphlet. In his advertisements Mann encouraged both attorneys and the general public to purchase copies. It was, he believed, "Necessary for every Person to possess who expects to Prosecute or Defend by this Law."36 Mann also printed the form, described in section twelve of the act, used as the recognizance.

As well as selling his own work, Mann advertised, recorded subscribers, and sold material for other printers. Shepard Kollock, his mentor, issued The United States Almanac beginning in I 780 , and in 1799 and I 800 placed copies in his former student's shop for local residents to purchase. ${ }^{37}$ Matthias Day, another Kollock apprentice who probably learned his trade alongside Mann, used the columns of the Genius of

\footnotetext{
${ }^{34}$ Genius of Liberty, July 5, $179^{8 .}$

35 "An Inventory of Caleb Russell," July 1805, New Jersey State Library, Trenton,

${ }^{36}$ Genius of Liberty, August 2, 1798 .

${ }^{37}$ Ibid., November 29, 1799, and subsequent issues through March 2 I, 1800.
} N.J. 
Liberty to solicit Morris County subscribers for his edition of the Laws of New Jersey. ${ }^{38}$ Two other Day imprints, The New Jersey Trooper's Pocket Companion and The American Trooper's Pocket Companion, were advertised and sold by Mann. ${ }^{39}$ Pennington and Gould of Newark announced in the November 27, I 800, number of the Genius of Liberty that they intended to issue by subscription Jefferson's Notes on the State of Virginia, and printers from New York and Philadelphia inserted notices regarding their publications. ${ }^{40}$ Since American printing was still in its infancy and since a country printing office, typically consisting of only one press, could not by itself meet the demand of local customers, it was common practice for one printer to sell the work of others. Rather than considering them competitors, Jacob Mann relied on their books and pamphlets as an extra source of income.

The development of printing in Morristown paralleled the development of printing in post-revolutionary America. After the war, opportunities were created for enterprising printers in sparsely settled but growing areas of the country. It was common for printers to leave established firms to fill the demand created by an increasingly mobile population. David Cree sought to exploit what he thought was a promising market in Morristown, but like so many of his contemporaries elsewhere, he failed in his efforts. A restless worker, Cree drifted from one place to another, finally finding himself in Philadelphia, where he took part in an early journeymen's strike in $1786 .^{41}$ Elijah Cooper, Morristown's second printer, had fled from New Hampshire and, after acquiring Caleb Russell as his financial sponsor, set up his shop. Like Cree, however, he did not remain for any length of time. Not until Jacob Mann's arrival did Morristown find someone who was both productive and a steady worker. When Mann left for a brief stay in Trenton in I 80 I, Russell's son Henry assumed the responsibilities of the printing shop; this suggests that he served under Mann as an apprentice. Evi-

${ }^{38}$ Ibid., December 6, 1798, and subsequent issues through January 10, 1799.

${ }^{39} \mathrm{Ibid}$., August 8, 1799, and subsequent issues through September 26, 1799.

${ }^{40}$ In the May 23, 1799, issue of the Genius of Liberty a new newspaper to be published in New York, the Columbian Gazette, was advertised. Birch and Small of Philadelphia announced their publication of the History of Modern Europe, by Dr. Russell in the September 25,1800 , issue.

${ }^{41}$ Although little is known about this Philadelphia strike, the incident is mentioned in: Ethelbert Stewart, "A Documentary History of the Early Organizations of Printers," Bulletin of the Bureau of Labor, no. 61 (November 1905):860; and in Rollo G. Silver, "Aprons Instead of Uniforms: the Practice of Printing, $1776-1787$," Proceedings of the American Antiquarian Society 87 (April i 977 ): 180. 
dently, a successful printing office could not survive in Morristown without the financial assistance of Caleb Russell and the interest of his family.

The publications drawn from the presses of Cree, Cooper, and Mann were representative of what was being printed in the country during the last decade of the eighteenth century. Since it was the ambition of nearly every printer active at this time to issue a newspaper, it is not surprising to find three from Morristown between 1784 and 1800 . Legal issues, political broadsheets and announcements, religious items, tributes to Washington, philosophical discussions, and diverting stories were all staples of the eighteenth-century American press. It is unfortunate that ephemeral material such as chapbooks, children's literature, public notices intended for short lives, and other street literature have not in most cases survived. Nor were records of printing offices generally kept in a systematic fashion, or retained after their immediate use. Discovering the products of eighteenth-century printers and reconstructing their often-migratory lives are, thus, most difficult tasks. ${ }^{42}$

\section{Bibliography of Morristown Imprints, $1784-1800^{43}$}

An Act of the Legislature of the State of New Jersey, Passed at Trenton, the I $5^{\text {th }}$ of March, I798, Authorizing Justices of the Peace to Take Cognizance in Civil Actions Therein Mentioned for Sixty' Dollars or Under. Jacob Mann, $179^{8}$.

An Address to the Citizens of the County of Morris. Jacob Mann, I 800.

Amusement-Hall; or a Collection of Diverting Stories, and Extraordinary Facts, with an Account of the Art of Ventriloquism; and other Entertaining Matter. Jacob Mann, I 799.

Carle, John I. A Funeral Sermon Preached at Rockaway, December 29th, I799 on the Much Lamented Death of General George Washington, who Departed this Life December I4th, I799, at Mount Vernon, in the Sixtyeighth Year of his Age. Jacob Mann, I 800.

${ }^{42}$ Clarence S. Brigham to Maud E. Johnson, ig March 1917, New Jersey Historical Society Archives. In this letter Brigham complains about the lack of primary source material available for the study of early American printers.

${ }^{43}$ Other bibliographies of Morristown imprints are: James H. Fraser, Early Printing in Morristown, New Jersey; a Bibliography of Morristown Imprints: $1798-1836$ (Morristown, Joint Free Public Library of Morristown and Morris Township, 1970); Douglas C. McMurtrie, "A Bibliography of Morristown Imprints, 1798-1820," Proceedings of the New Jersey Historical Society 54 (April 1936):129-155; Lucile M. Morsch, "A Checklist of New Jersey Imprints, 1784-1800" (M.A. thesis, Columbia University, 1 930); William Nelson, Checklist of the Press of New Jersey, pp. 19-20; and Grace D. Rose, "Early Morristown Imprints," Proceedings of the New Jersey Historical Society 53 (July 1935): 156-163. 
Genius of Liberty. Jacob Mann, 1798-1800.

Knox, Vicesimus. Spirit of Despotism. Jacob Mann, I 799.

[Letter circulated in the congregation of the Morristown Presbyterian Church] Jacob Mann, 1798.

A Memorial of the Respect Paid to the Man First in War-First in Peace, and First in the Affections of the American People. Jacob Mann, I 800.

[Morris County Civil List] Jacob Mann, 1799.

Morris County Gazette. Elijah Cooper, Jacob Mann, I797-1798.

Morristown Gazette and New Jersey Advertiser. David Cree, 1784.

Report of the Committee of the House of Representatives of the United States Appointed to Prepare and Report Articles of Impeachment A gainst William Blount, a Senator of the United States, Impeached of High Crimes and Misdemeanors. Jacob Mann, 1798.

Republican Meeting ... to the Citizens of the County of Morris. Jacob Mann, I 800 . 